\title{
Length-Weight Relationships for Three Deep Sea Fish Species in North Eastern Mediterranean, Turkey
}

\author{
Yusuf Kenan Bayhan' ${ }^{1}$ (D), Sibel Alagöz Ergüden² (D), Deniz Ergüden ${ }^{3}$ (D)
}

Cite this article as: Bayhan, Y. K., Alagoz Erguden, S. \& Erguden, D. (2020). Length-weight relationships for three deep sea fish species in North Eastern Mediterranean, Turkey. Aquatic Sciences and Engineering, 35(3), 89-93.

ORCID IDs of the author: Y.K.B. 0000-0002-7403-900X; S.A.E. $0000-0003-4363-433 X$ D.E. 0000-0002-2597-2151

'Adıyaman University, Vocational School Kahta, Department of Fisheries, Adıyaman, Turkey

${ }^{2}$ Çukurova University, Vocational School Imamoglu, Department of Fisheries, Adana, Turkey

3ंskenderun University, Faculty of Marine Sciences and Technology, Department of Marine Science,

Technical, Hatay, Turkey

Submitted:

02.02.2020

Revision Requested: 13.03.2020

Last Revision Received:

19.03.2020

Accepted:

05.04.2020

Online published:

20.05.2020

Correspondence:

Sibel Alagöz Ergüden

E-mail:

alagozs@cu.edu.tr;

sibelerguden@gmail.com

(C) Copyright 2020 by Aquatic

Sciences and Engineering

Available online at

https://dergipark.org.tr/ase

\begin{abstract}
In the present study, length-weight relationships (LWRs) were estimated for three deep sea fish species, namely, Nettastoma melanura Rafinesque, 1810; Lampanyctus crocodilus (Risso, 1810); and Chauliodus sloani Bloch \& Schneider, 1801 in the north-eastern Mediterranean Sea. A total of 102 fish samples were collected from Mersin Bay (Erdemli coast). Their length-weight relationship b values ranged between 2.458 and 3.496, and all regressions were found to be significant for all three species $(p<0.001)$. This study is the first reference on length-weight relationships for these three deep-sea fish species from the North-eastern Mediterranean Sea coast of Turkey. Besides, Length-weight relationships for C. sloani and L. crocodilus were not yet available in Fishbase for the Eastern Mediterranean, and hence these results obtained from this study will be useful to researchers and fisheries biologists in the field.
\end{abstract}

Keywords: Deep sea fishes, Length-weight parameters, Blackfin sorcerer, Jewel lanternfish, Sloane's viperfish, Mersin Bay

\section{INTRODUCTION}

In fisheries biology and fisheries management, length-weight relationships (LWRs) data are useful to determine the weight of an individual fish of known length or total weight from the length-frequency distribution (Garcia, Buarte, Sandoval, Von Schiller, \& Mello, 1989; Froese, 1998; Koutrakis \& Tsikliras, 2003). Besides, these relationships are an important component of FishBase (Froese \& Pauly, 2019).

To date, there are a limited number of studies on the population of three deep-sea fish species length-frequency distributionin the western Mediterranean (Merella, Quetglas, Alemany, \& Carbonell, 1997 Porcu et al., 2013) and eastern Mediterranean (Bílge, Yapici, Fíliíz, \& Cerím, 2014; Deval, Güven, Saygu, \& Kabapçioğlu, 2014).

The present study shows the first-time results of an investigation of length-weight relationships of three deep-sea fish species: Blackfin sorcerer, Nettastoma melanura Rafinesque, 1810; Jewel lanternfish, Lampanyctus crocodilus (Risso, 1810); and Sloane's viperfish Chauliodus sloani Bloch \& Schneider, 1801 from Mersin Bay (N.E. Mediterranean, Turkey).

Although biological studies on the deep sea fish fauna are limited in the Mediterranean Sea, this paper provides the first information on the length-weight relationships of three deep sea fish species in the North eastern Mediterranean Sea coast of Turkey. Besides, Length-weight relationships for C. sloani and L. crocodilus were not yet available in Fishbase for the Eastern Mediterraenan.

\section{MATERIALS AND METHODS}

\section{Study area}

The present study recorded deep sea fish specimens from the Mersin Bay Erdemli coast, Tur- 
key) (Figure 1). Mersin Bay is an important fishing area of the Northeastern Mediterranean Sea due to its nutrient-rich fresh water inputs.

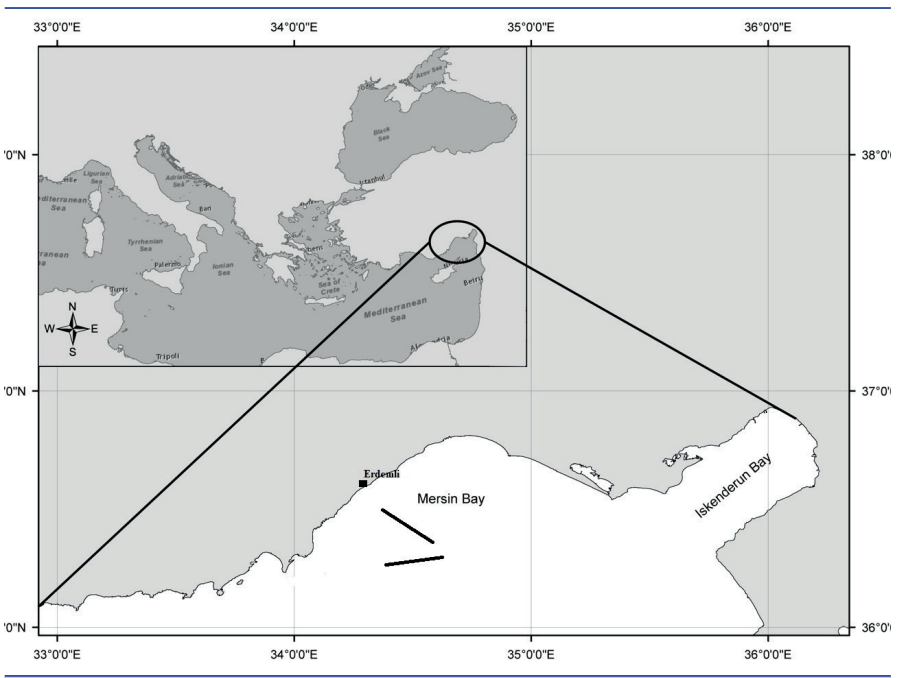

Figure 1. Sampling area.

During the sea surveys, 102 deep sea fish specimens belonging to three family were caught by commercial bottom trawler at a depth of 400 to $595 \mathrm{~m}$ off Mersin Bay (Erdemli coast) (Coordinates; $36^{\circ} 12^{\prime} 383 \mathrm{~N}-034^{\circ} 23^{\prime} 019^{\prime \prime} \mathrm{E} ; 36^{\circ} 08^{\prime} 926^{\prime \prime} \mathrm{N}-034^{\circ} 42^{\prime}$ 057" E). Samplings were carried out between June and July 2019. The trawler was equipped with $44 \mathrm{~mm}$ stretched mesh size nets at the cod-end. Trawling lasted 4 hours and the trawling speed was 2.7 knots (Figure 1). Captured fish specimens were photographed on board and then preserved in ice boxes for examination in the laboratory.In the laboratory, each fish was measured for total length to the nearest $0.1 \mathrm{~cm}$, weight was measured to the nearest $0.1 \mathrm{~g}$, and the sex was determined by macroscopic observation of the gonads.

Estimation of the length-weight relationship was made by adjustment of an exponential curve to the data (Ricker, 1975): $W=a L^{b}$. Where; W is body weight $(\mathrm{g}), \mathrm{L}$ is total length $(\mathrm{cm})$, a is a coefficient related to body form, and $\mathrm{b}$ is an exponent indicating isometric growth when equal to 3 (Beverton \& Holt, 1996). The parameters a and $b$ were estimated by linear regression on the transformed equation: $\log (W)=\log (a)+b \log (L)$. The $b$ value for each species was tested by a t-test at the $p=0.05$ significance level to verify if it was significantly different from 3 (Pauly, 1993). All statistical analyses were performed using SPSS v. 21.0. Species identification was done according to Whitehead et al. (1986). The scientific name for each species was checked against FishBase (Froese \& Pauly, 2019).

\section{RESULTS}

Lengths ( $T L$ ) and weights $(\mathrm{g})$ of a total of 102 fish specimens belonging to 3 fish species from 3 families were measured, recorded and analyzed (Figure 2, Figure 3, and Figure 4). The sample size, minimum maximum length as well as the LWRs, the coefficient of determination $\left(r^{2}\right)$, the standard error and confidence interval $(\mathrm{Cl})$ of $b$ for each species are presented in Table 1.

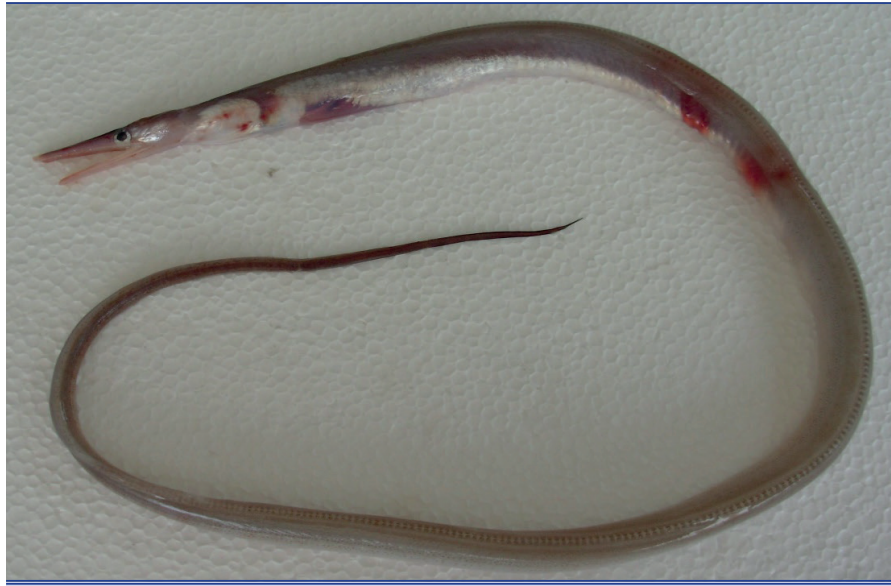

Figure 2. Nettastoma melanura Rafinesque, 1810 in the North-eastern Mediterranean.

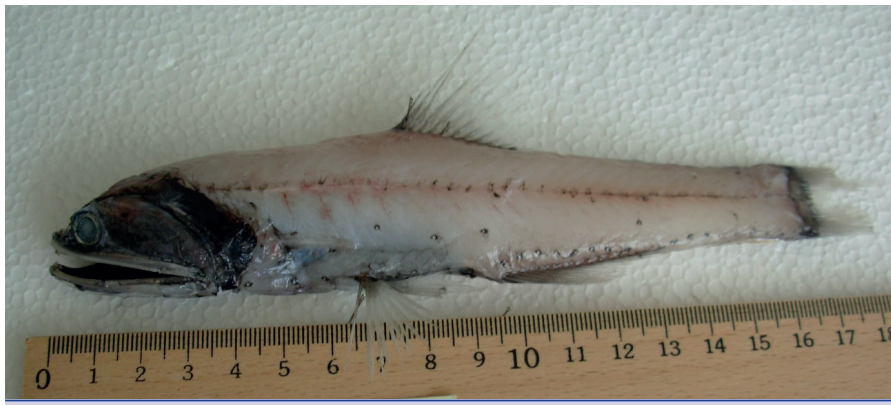

Figure 3. Lampanyctus crocodilus (Risso, 1810) in the Northeastern Mediterranean.

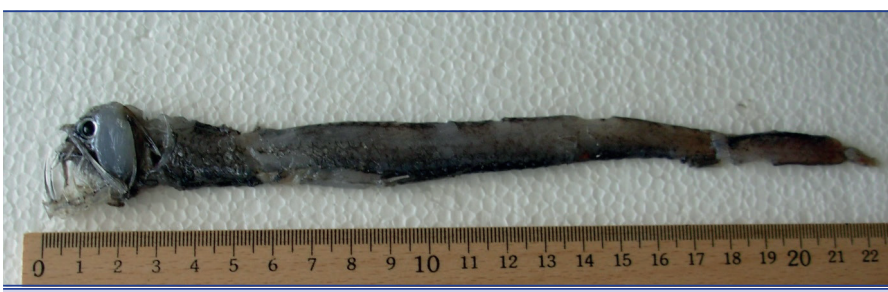

Figure 4. Chauliodus sloani Bloch \& Schneider, 1801 in the North-eastern Mediterranean.

The exponent $b$ often has a value close to three, but varies between two and four (Tesch 1971).In the present study, b values (based on $\mathrm{TL}$ ) of the $N$. melanura species were negative allometric growth for males, females and sexes combined $(b<3)$. However, $b$ values of $L$. crocodilus and C. sloani were positive allometric growth for males, females and sexes combined $(b>3)$, (t-test: $\mathrm{p}<0.05)$.

In the present study, 102 specimens had b values within the expected range of 2.5-3.5 (Bílge et al., 2014; Deval et al., 2014) for three deep sea fish species (N. melanura, C. sloani and L. crocodilus). The calculated allometric coefficient $b$ ranged from a minimum of 2.458 for males of N.melanura, to a maximum 3.496 for males of $L$. crocodilus. All regression values were found to be highly significant $(p<0.001)$, with the coefficient of determination $\left(r^{2}\right)$ values being $>0.95$ for all three fish species (Table 1 ). 
Table 1. Descriptive statistics and length-weight relationships (LWRs) for three deep-sea fish species, North-eastern Mediterranean coast of Turkey.

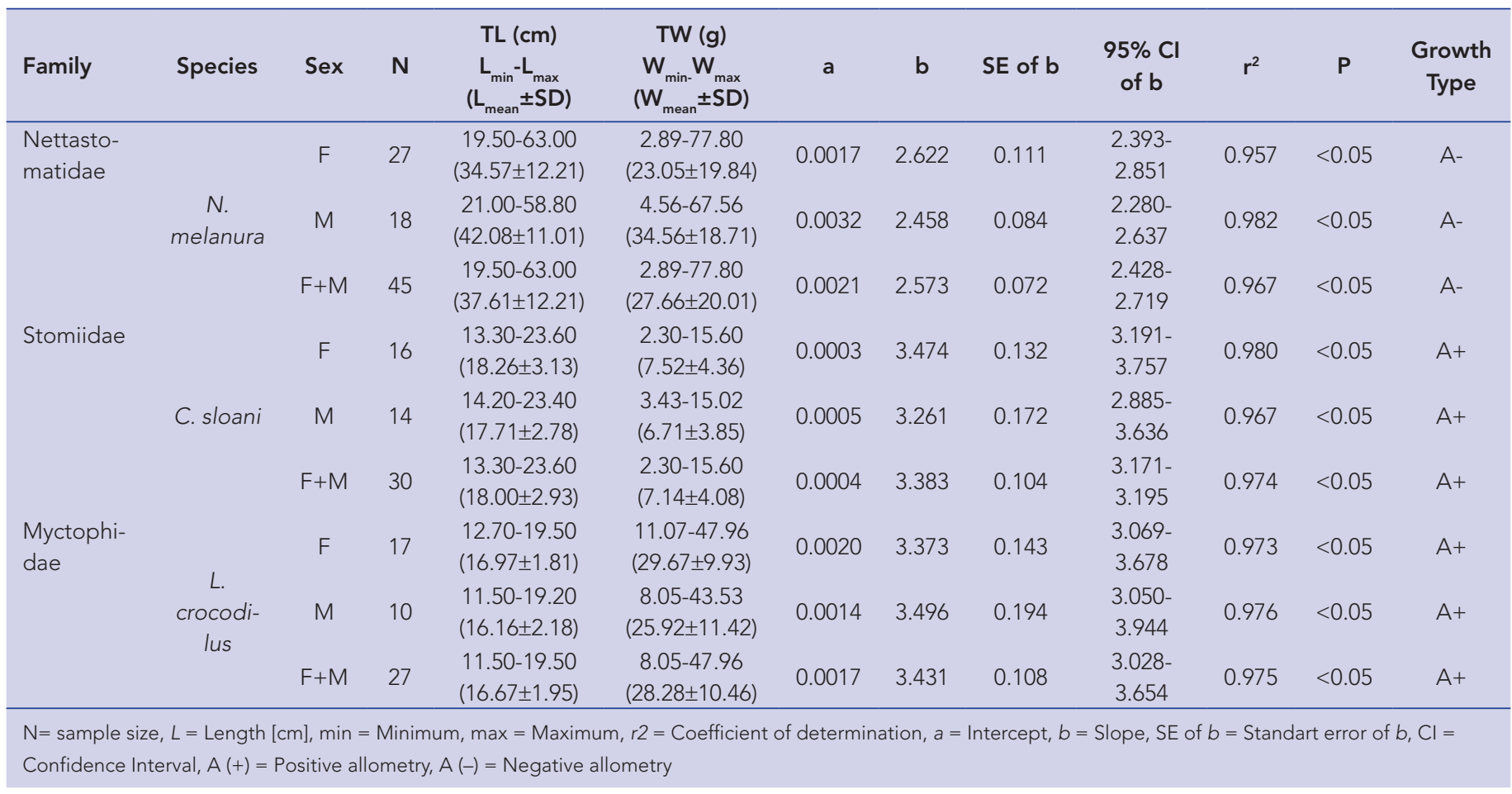

Table 2. Length-weight relationships of three deep-sea fish species from different geographical areas.

\begin{tabular}{|c|c|c|c|c|c|c|c|c|c|c|}
\hline Reference & Locality & Country & Species & Sex & $\mathbf{N}$ & $\begin{array}{l}\mathrm{TL}(\mathrm{cm}) \\
\mathrm{L}_{\min }-\mathrm{L}_{\max }\end{array}$ & $\begin{array}{c}\text { TW (g) } \\
\mathrm{W}_{\min -} \mathrm{W}_{\max }\end{array}$ & a & b & $r^{2}$ \\
\hline $\begin{array}{l}\text { Deval et al. } \\
\text { (2014) }\end{array}$ & $\begin{array}{c}\text { Antalya Bay, } \\
\text { eastern } \\
\text { Mediterranean }\end{array}$ & Turkey & $\begin{array}{c}\text { Nettastoma } \\
\text { melanura }\end{array}$ & Mixed & 75 & $25.1-79.8$ & $5.4-255.5$ & 0.00020 & 3.180 & 0.940 \\
\hline \multirow{2}{*}{$\begin{array}{l}\text { Porcu et al. } \\
\text { (2013) }\end{array}$} & \multirow{2}{*}{$\begin{array}{l}\text { South-eastern } \\
\text { Sardinian Sea }\end{array}$} & \multirow{2}{*}{ Italy } & \multirow{2}{*}{$\begin{array}{c}\text { Nettastoma } \\
\text { melanura }\end{array}$} & Male & 171 & $30.2-66.8$ & - & 0.00200 & 3.247 & 0.820 \\
\hline & & & & Female & 226 & $32.5-75.3$ & - & 0.00004 & 3.602 & 0.860 \\
\hline Bílge et al. (2014) & $\begin{array}{c}\text { Southern } \\
\text { Aegean Sea }\end{array}$ & Turkey & $\begin{array}{c}\text { Lampanyctus } \\
\text { crocodilus }\end{array}$ & Mixed & 80 & $9.4-16.2$ & - & 0.00690 & 3.143 & 0.967 \\
\hline $\begin{array}{l}\text { Merella et al. } \\
\text { (1997) }\end{array}$ & $\begin{array}{l}\text { Balearic Islands } \\
\text { (western } \\
\text { Mediterranean) }\end{array}$ & Spain & $\begin{array}{c}\text { Lampanyctus } \\
\text { crocodilus }\end{array}$ & Mixed & 25 & $9.0-21.0$ & - & 0.00510 & 2.980 & 0.990 \\
\hline $\begin{array}{l}\text { Merella et al. } \\
\text { (1997) }\end{array}$ & $\begin{array}{l}\text { Balearic Islands } \\
\text { (western } \\
\text { Mediterranean) }\end{array}$ & Spain & $\begin{array}{l}\text { Chauliodus } \\
\text { sloani }\end{array}$ & Mixed & 11 & $15.1-30.5$ & - & 0.00090 & 3.180 & 0.988 \\
\hline
\end{tabular}

The length-weight relationship for the three deep sea fish species was found as $W=0.0021 L^{2.573}\left(R^{2}=0.967\right)$ for $N$. melanura, $W=0.0004$ $L^{3.383}\left(R^{2}=0.974\right)$ for $C$. sloani and $W=0.0017 L^{3.431}\left(R^{2}=0.975\right)$ for $L$. crocodilus. Estimation of length-weight relationship of combined sexes for the three fish species are given in Figure 5.

Porcu et al. (2013) reported positive allometric growth (male; $b=3.247$, female; $b=3.602$ ) for $N$. melanura from South-eastern Italy. Similarly, Deval et al. (2014) stated in the Antalya Bay, Turkey positive allometric growth $(b=3.180)$, Bílge et al. (2014) reported positive allometric growth $(b=3.143)$ for $L$. crocodilus in the study conducted from the southern Aegean Sea, Turkey, and Merella et al. (1997) reported in the western Mediterranean negative allometric growth $(b=2.980)$ for $L$. crocodilus andpositive allometric growth $(b=3.180)$ for $C$. sloani.

The previous studies on the presence for length characteristics of the length-weight relationships of the three deep-sea fish species in the other Mediterranean regions are given in Table 2. For all of the studied species presented in this paper, the b val- 


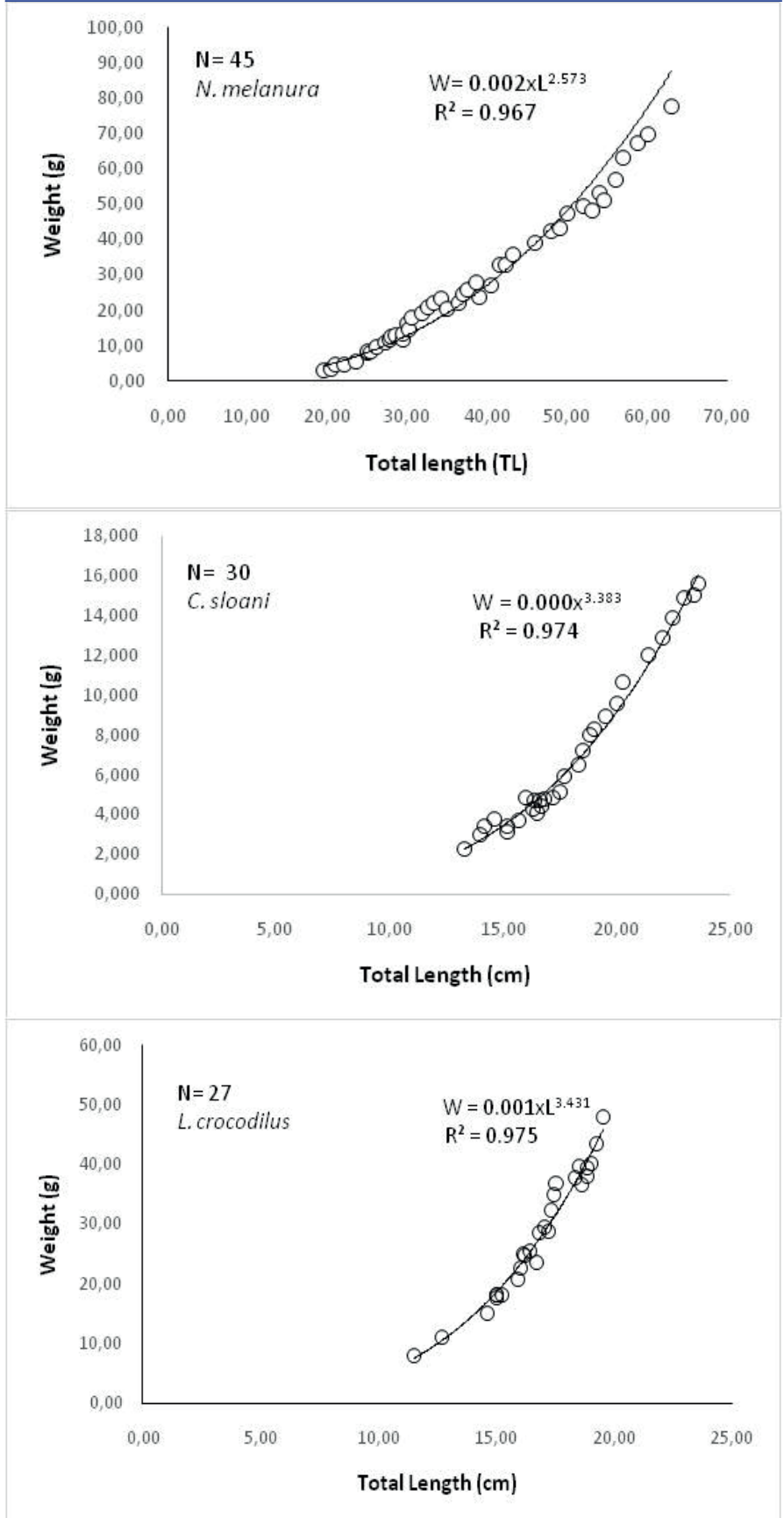

Figure 5. Length-weight relationship of combined sexes for three deep-sea fish species from the North-eastern Mediterranean, Turkey.

ues were generally in agreement with results for fishes of the same family obtained from other geographical regions except for $N$. melanura. These differences for $N$. melanura could be the result of ecological differences between regions or environmental differences (Frost, 1945). At the same time, the differences in the sampling time and sampling methods may also affect the relationships, as the numbers of specimens and length ranges of the species were distinct among localities (Tesch, 1971; Froese, 2006).
Length and weight relationships are used widely in fish exploration and supervision, and LWRs are essential to recognize the ecology and life of fish species (Froese, 2006). However, the length-weight relationship in fishes is affected by a number of factors including season, habitat, gonad, sex, diet and stomach fulness and preservation techniques (Tesch, 1971; Bagenal and Tesch, 1978), all of which were not accounted for in the present study.

\section{CONCLUSION}

The present study was conducted to give length and weight data of three fish species. To date, no information regarding the $C$. sloani and L. crocodilus fish species for the Eastern Mediterranean is available in Fishbase (Froese \& Pauly, 2019).

To the best knowledge of the authors, this study presented the first compherensive reference on length-weight relationships for three deep sea fish species from the Eastern Mediterranean coast of Turkey. The results obtained from this study are useful to researchers and fisheries biologists, because the data were sampled from a fairly deep waters area.

Conflicts of interest: The authors have no conflicts of interest to declare.

Ethics committee approval: This study was conducted in accordance with the ethics committee procedures of animal experiments.

Acknowledgments: We would like to thank the owner of the Çınar Bey boat, captain Murat ÇINAR, andthe boat staff for their valuable support in this study.

\section{REFERENCES}

Bagenal, T. B. \& Tesch, F. W. (1978). Methods for assessment of Fish Production in Fresh Waters, (3rd ed.). IBP Handbook No. 3. In T. Bagenal (Ed.)., (pp 101-136). London: Blackwell Scientific Publications, Oxford.

Beverton, R. J. H. \& Holt, S. J. (1986). On the dynamics of exploited fish populations. London: Chapman and Hall.

Bílge, G., Yapici, S., Fíliíz, H. and Cerím, H. (2014). Weight-length relationshions for 103 fish species from the southern Aegean sea, Turkey. Acta Ichthyologica et Piscatoria, 44(3), 263-269. [CrossRef]

Deval, M. C., Güven, O. Saygu, I. \& Kabapçioğlu, T. (2014). Length-weight relationships of 10 fish species found off Antalya Bay, eastern Mediterranean. Journal of Applied Ichthyology, 30(3), 567-568. [CrossRef]

Froese, R. (2006). Cube law, condition factor and weight-length relationships: history, meta-analysis and recommendations. Journal of Applied Ichthyology, 22(4), 241-253. [CrossRef]

Froese, R. (1998). Length-weight relationships for 18 less-studied fish species. Journal of Applied Ichthyology, 14, 117-118. [CrossRef]

Froese, R. \& Pauly, D. (2019). Fishbase. Worldwide Web Electronic Publication. Retrieved from http://www.fishbase.org (accessed 27.12.2019).

Frost, W. E. (1945). The age and growth of eels (Anguilla anguilla) from the Windermere catchment area. Part 2. Journal of Animal Ecology, 14, 106-I24. [CrossRef]

Garcia, C. B., Buarte, J. O., Sandoval, N., Von Schiller, D. \& Mello, N. P. (1989). Length-weight relationships of demersal fishes from the Gulf of Salamanca, Colombia. Fishbyte, 21, 30-32. 
Koutrakis, E. T. \& Tsikliras, A. C. (2003). Length-weight relationships of fishes from three northern Aegean estuarine systems (Greece). Journal of Applied Ichthyology, 19, 258-260. [CrossRef]

Merella, P., Quetglas, A., Alemany, F. \& Carbonell, A. (1997). Lengthweight relationship of fishes and cephalopods from the Balearic Islands (western Mediterranean). Naga, the ICLARM Quarterly, 20(3/4), 66-68

Pauly, D. (1993). Fishbyte section editorial. Naga, the ICLARM Quarterly, $16,26$.

Porcu, C., Follesa, M. C., Gastoni, A., Mulas, A., Pedoni, C. \& Cau, A. (2013). The reproductive cycle of a deep-sea eel, Nettastoma melanurum (Nettastomatidae: Anguilliformes) from the southeastern Sardinian Sea (central-western Mediterranean). Journal of the Marine Biological Association of the United Kingdom, 93(4), 1105-1115. [CrossRef]

Ricker, W. E. (1975). Computation and interpretation of biological statistics of fish populations. Bulletin of the Fisheries Research Board of Canada, Bulletin, 191, 1-400.

Tesch, F. W. (1971). Age and growth. In: W. E. Ricker (Ed.), Methods for assessment of fish production in fresh waters (pp 99-130). Oxford, Blackwell Scientific Publications.

Whitehead P. J. P., Bauchot M. L., Hureau J. C., Nielsen J., \& Tortonese E. (Eds.) (1986). Fishes of the north-eastern Atlantic and the Mediterranean. Vols. I-III, UNESCO, Paris 1473 pp. ISBN: 92-3002215-2. 
Aquat Sci Eng 2020; 35(3): 89-93

Bayhan et al. Length-Weight Relationships for Three Deep Sea Fish Species in North Eastern Mediterranean, Turkey 